\title{
Promising Technologies for Remediation of warfare Nerve Agents and Pesticides: Biodegradation and Non-Biological Applications
}

\author{
Teodorico C Ramalho ${ }^{1,2 *}$ and Alexandre A de Castro ${ }^{1}$ \\ ${ }^{1}$ Department of Chemistry, Federal University of Lavras, Brazil \\ ${ }^{2}$ Center for Basic and Applied Research, University of HradecKralove, Brazil
}

Submission: April 18, 2017; Published: April 26, 2017

"Corresponding author: Teodorico C Ramalho, Department of Chemistry, Federal University of Lavras, 37200-000, Lavras, 2Center for Basic and Applied Research, Faculty of Informatics and Management, University of HradecKralove, Rokitanskeho 62, 50003, Czech Republic, Brazil, Email: teo@dqi.ufla.br

\begin{abstract}
The importance of chemical weapons as a current overall threat in possession of terrorist groups, along with a constant increase of pesticides usage, leading to intoxications frames and contaminations into the environment around the world, have kept the attention of researchers in order to develop new technologies for a rapid and complete detoxification of the poisoning caused by these organophosphorus compounds (OP). The standard treatment includes the usage of reactivator compounds, such as the so-called oximes. Other important remediation processes involve the employment of bioremediation techniques using different degrading enzymes, such as Phosphotriesterase, Human Serum Paraoxonase 1, Diisopropyl fluorophosphatase, among others. In addition to these promising treatments, there is also the possibility of using non-biological materials in the degradation process, such as some metal oxides clusters.
\end{abstract}

Keywords: Neurotoxic agents; Reactivators; AChE; Remediation processes

\section{Introduction}

In the period of the First World War, several nations gave rise to chemical warfare programs in order to get advantages in their fighting performance. Posteriorly, these activities were intensified during the Second Big War, mostly due to the discovery of organophosphorus nerve agents [1]. According to Jang et al. [2] the nerve agents are supposed to be the most dangerous compounds ever used. These substances are known for actively act on Acetylcholinesterase (AChE) enzyme. The OP chemical structure is responsible for the high toxicity in mammals regarding similar species. OPs are chemical compounds that have several applications, but these substances are generally employed as pesticides and chemical weapons [2,3]. Currently in the agricultural field, pesticides such as Diazoxon, Parathion and Paraoxon are widely employed to provide protection to crops from pests and insects that cause damages to theses cultures. However, these products are quite toxic, causing adverse and harmful effects to human health, acting directly on the central and peripheral nervous system, thus giving rise to neuromuscular abnormalities that can lead to death [4].
Neuroscience researches aim to comprehend the impacts caused by these agents and how they can affect humans [5], being these efforts necessary to get new remediation techniques $[6,7]$.<smiles>CCOP(=O)(OCC)Oc1ccc([N+](=O)[O-])cc1</smiles>

Ethyl paraoxon<smiles>CCOP(N)(=O)N(C)C</smiles>

Tabun<smiles>CC(OP(C)(=O)F)C(C)(C)C</smiles>

Soman

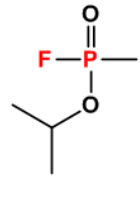

Sarin<smiles>CP(=O)(F)OC1CCCCC1</smiles>

Cyclosarin<smiles>CCOP(C)(=O)SCCCN(C(C)C)C(C)C</smiles>

vX

Figure 1: Chemical structure of OPcompounds. The leaving group of each agent is highlighted in red. 
OP insecticides and chemical warfare agents were developed to act as irreversible AChE inhibitors [8]. The general OP structure is constituted by a phosphoryl group $(\mathrm{P}=0)$ or a thiophosphoryl group $(\mathrm{P}=\mathrm{S})$, two lipophilic $\mathrm{R}$ groups, and the characteristic leaving group of each compound. The structures of one of the major pesticide (Ethyl paraoxon) and some main chemical warfare agents (Tabun, Soman, Sarin, Cyclosarin, VX) are shown in Figure $1[9,10]$. OPs are highly lipophilic compounds and rapidly move to the nervous system, with the subsequent initiation of the intoxication through the binding and posterior inactivation of AChE [8].

\section{Toxicology and Remediation perspectives}

After AChE inhibition by OP, two processes can take place: (a) aging of AChE and (b) spontaneous reactivation of the enzyme, which happen at an insignificant rate. The reactivation process can be sped up by adding a strong nucleophile, such as oximes. Other promising techniques, which aim to provide an efficient detoxificationare the enzymatic biodegradation treatments [11-13]. It is well-known that traditional techniques for OP detoxification are commonly expensive; in this context, bioremediation processes are recently a good alternative for this purpose, along with the use of specific antidotes. The enzymes Human Serum Paraoxonase 1 (HssPON1), Diisopropyl fluorophosphatase (DFPase) and Phosphotriesterase (PTE) have been shown to be appropriate for high performance decontamination applications $[14,15]$. These enzymes usually present a binuclear metal center which is directly related to the hydrolysis reaction mechanism, being responsible for maintaining the structural integrity and also for the catalytic activity [16]. In this context, metal clusters have been designed in order to efficiently mimic an enzyme active site in the catalysis; as an example of application, there is the collaboration from Katz et al., wherein it was employed a zirconium (IV)-cluster-containing metal-organic framework as an active biomimetic catalyst, presenting a great activity and selectivity for the hydrolysis of paraoxon. This good performance is believed to be related to the set $\mathrm{Zr}-\mathrm{OH}-\mathrm{Zr}$, which interestingly mimic the binuclear metal center (a couple of Zn2+ ions) of the PTE enzyme [17].

\section{Conclusion}

Chemical weapons represent a major concern to the society due to their devastating effects. Equally important, the misuse of OP pesticides can cause serious damages to public health and the environment, leading to death thousands of victims annually. Therefore, the search for more efficient tools capable of providing rapid and complete detoxification has been quite important nowadays. Thus, the purpose of this collaboration is to bring about promising possibilities, such as the employment of degrading enzymes (bioremediation) and non-biological systems, which can provide great contributions to the medicinal chemistry, and also stimulate more and more researches in this filed, which is undoubtedly of significant importance and interest.

\section{Acknowledgment}

The authors wish to thank Coordenação de Aperfeiçoamento de Pessoal de Nível Superior (CAPES) for financial support, and Federal University of Lavras (UFLA) for providing the physical infrastructure and working space. This work has been supported by Fakultainformatiky a managementu-Univerzita Hradec Králové, which has brought about excellence collaboration to this project

\section{References}

1. Balali-Mood M, Abdollahi M (2014) Basic and Clinical Toxicology of Organophosphorus Compounds. London: Springer International Publishing.

2. Jang YJ, Kim K, Tsay OG, Atwood DA, Churchill DG (2015) Update 1 of: Destruction and Detection of Chemical Warfare Agents. Chemical Reviews 115(24): PR1-76.

3. Voorhees JR, Rohlman DS, Lein PJ, Pieper AA (2017) Neurotoxicity in Preclinical Models of Occupational Exposure to Organophosphorus Compounds. Frontiers in Neuroscience 10: 590.

4. Cavalcanti LPAN, Aguiar AP, Lima JA, Lima ALS (2016) Organophosphorous Poisoning: Treatment and Analytical Methodologies Applied in Evaluation of Reactivation and Inhibition of Acetylcholinesterase. Revista Virtual de Química 8(3).

5. Kim K, Tsay OG, Atwood DA, Churchill DG (2011) Destruction and Detection of Chemical Warfare Agents. Chemical Reviews 111(9): 5345-5403.

6. Ramalho TC, de Castro AA, Silva DR, Silva MC, Franca TCC, et al. (2016) Computational Enzymology and Organophosphorus Degrading Enzymes: Promising Approaches Toward Remediation Technologies of Warfare Agents and Pesticides. Current Medicinal Chemistry 23(10): 1041-1061.

7. De Castro AA, Caetano MS, Silva TC, Mancini DT, Rocha EP, et al. (2016) Molecular Docking, Metal Substitution and Hydrolysis Reaction of Chiral Substrates of Phosphotriesterase. Combinatorial Chemistry \& High Throughput Screening 19(4): 334-344.

8. Iyer R, Iken B, Leon A (2015) Developments in alternative treatments for organophosphate poisoning. Toxicology Letters 233(2): 200-206.

9. Saint-André G, Kliachyna M, Kodepelly S, Louise-Leriche L, Gillon Eet al. (2011) Design, synthesis and evaluation of new $\alpha$-nucleophiles for the hydrolysis of organophosphorus nerve agents: Application to the reactivation of phosphorylated acetylcholinesterase. Tetrahedron 67(34): 6352-6361.

10. Patočka J, Cabal J, Kuča K, Jun D (2005) Oxime reactivation of acetylcholinesterase inhibited by toxic phosphorus esters: In vitro kinetics and thermodynamics. Journal of Applied Biomedicine 3(2): 91-99.

11. Nachon F, Brazzolotto X, Trovaslet M, Masson P (2013) Progress in the development of enzyme-based nerve agent bioscavengers. ChemicoBiological Interactions 206(3): 536-544.

12. Sartorelli J, de Castro AA, Ramalho TC, Giacoppo JOS, Mancini DT, et al. (2016) Asymmetric biocatalysis of the nerve agent VX by human serum paraoxonase 1: molecular docking and reaction mechanism calculations. Medicinal Chemistry Research 25(11):2521-2533.

13. Efremenko EN, Lyagin IV, Klyachko NL, Bronich T, Zavyalova NV, et al (2017) A simple and highly effective catalytic nanozyme scavenger for organophosphorus neurotoxins. Journal of Controlled Release 247: 175-181. 
14. Omburo GA, Kuo JM, Mullins LS, Raushel FM (1992) Characterization of the Zinc-Binding Site of Bacterial Phosphotriesterase. Journal of Biological Chemistry 267(19): 13278-13283.

15. Wymore T, Field MJ, Langan P, Smith JC, Parks JM (2014) Hydrolysis of DFP and the nerve agent (S)-sarin by DFPase proceeds along two different reaction pathways: Implications for engineering bioscavengers. Journal of Physical Chemistry B 118(17): 4479-4489.
16. Field MJ, Wymore TW (2014) Multiscale modeling of nerve agent hydrolysis mechanisms: a tale of two Nobel Prizes. Physica Scripta 89(10): 1-11.

17. Katz MJ, Mondloch JE, Totten RK, Park JK, Nguyen ST, et al. (2014) Simple and Compelling Biomimetic Metal-Organic Framework Catalyst for the Degradation of Nerve Agent Simulants. Angewandte Chemie International Edition 53(2): 497-501.

\section{Your next submission with Juniper Publishers will reach you the below assets}

- Quality Editorial service

- Swift Peer Review

- Reprints availability

- E-prints Service

- Manuscript Podcast for convenient understanding

- Global attainment for your research

- Manuscript accessibility in different formats ( Pdf, E-pub, Full Text, Audio)

- Unceasing customer service

Track the below URL for one-step submission https://juniperpublishers.com/online-submission.php 